\title{
Corn nutrition and yield as a function of boron rates and zinc fertilization
}

\section{Avaliação nutricional e produtividade do milho em função de doses de boro e adubação com zinco}

\author{
Lais Meneghini Nogueira ${ }^{1}$; Marcelo Carvalho Minhoto Teixeira Filho²; \\ Márcio Mahmoud Megda ${ }^{3}$; Fernando Shintate Galindo ${ }^{1 *}$; Salatiér Buzetti²; \\ Cleiton José Alves ${ }^{1}$
}

\begin{abstract}
Brazilian Cerrado soils are commonly deficient in boron (B) and zinc ( $\mathrm{Zn})$. It is still debated whether B and $\mathrm{Zn}$ interaction has a synergistic or antagonistic effect on the absorption thereof. Thus, we conducted this study to evaluate the effect of boron rates $\left(0,1,2,3\right.$, and $4 \mathrm{~kg} \mathrm{ha}^{-1}$, as boric acid), with or without zinc fertilization $\left(2 \mathrm{~kg} \mathrm{ha}^{-1} \mathrm{Zn}\right.$, as zinc sulfate), on corn nutritional status and grain yield. We also assessed the residual effect of such fertilization on the fall corn crop grown on an Oxisol in a no-tillage system. A synergistic effect between B and $\mathrm{Zn}$ was observed on corn nutritional status when applied to the soil at rates of up to $2 \mathrm{~kg} \mathrm{ha}^{-1}$, with higher soil contents resulting from the interaction between these micronutrients. Zinc fertilization and increasing boron rates had no significant influence on corn grain yield in both spring/summer and fall crops, grown on a boron-deficient, clayey soil of Cerrado biome. Key words: Borated fertilizer. Boric acid. Micronutrients. Nutrient concentrations. Zea mays L.
\end{abstract}

\section{Resumo}

Solos do Cerrado Brasileiro são comumente deficientes em boro (B) e zinco (Zn). Muito se discute a respeito da interação entre $\mathrm{B}$ e $\mathrm{Zn}$, em função de um possível efeito sinérgico ou antagônico na absorção desses nutrientes, desta forma o objetivo com este estudo foi avaliar o efeito das doses de boro. $\left(0,1,2,3\right.$, e $4 \mathrm{~kg} \mathrm{ha}^{-1}$, na forma de ácido bórico), com ou sem adubação com zinco (2 kg ha-1 $\mathrm{Zn}$, na forma de sulfato de zinco), avaliando o estado nutricional e a produtividade de grãos de milho, além do efeito residual desta adubação no solo no cultivo de milho subsequente, em um Latossolo Vermelho distrófico em plantio direto. Houve efeito sinérgico no estado nutricional do milho entre B e $\mathrm{Zn}$ aplicado ao solo em doses de até $2 \mathrm{~kg} \mathrm{ha}^{-1}$, com maiores concentrações no solo decorrentes da interação desses micronutrientes. A adubação com zinco e as doses crescentes de boro não influenciaram significativamente a produtividade de grãos de milho primavera/ verão e outono em um solo argiloso com deficiência de boro em condições de Cerrado.

Palavras-chave: Fertilização borratada. Ácido bórico. Micronutrientes. Concentração de nutrientes. Zea mays L.

1 Mestres em Agronomia, Sistemas de Produção, Programa de Pós-Graduação em Agronomia, Universidade Estadual Paulista, UNESP, Campus de Ilha Solteira, Ilha Solteira, SP, Brasil. E-mail: lais-meneghini@hotmail.com; fs.galindo@yahoo.com.br; cleiton.agr. feis@gmail.com

2 Profs. Drs., UNESP, Ilha Solteira, SP, Brasil. Bolsistas em produtividade de pesquisa pelo Conselho Nacional de Desenvolvimento Científico e Tecnológico, CNPq. E-mail:mcmtf@yahoo.com.br; sbuzetti@agr.feis.unesp.br

3 Prof. Dr., Universidade Estadual de Montes Claros, UNIMONTES, Janaúba, MG, Brasil. E-mail: marcio_agr@yahoo.com.br

* Author for correspondence 


\section{Introduction}

A proper nutrient supply (amount, source, method, and time) is fundamental to improve corn growth and yield. Some strategies can be used to achieve high and profitable corn yields such as seeding at optimal time and growing suitable genotypes for each region, as well as ensuring proper nutrient balance and supply (GALINDO et al., 2016).

Under tropical conditions, micronutrient deficiencies of boron (B) and zinc ( $\mathrm{Zn}$ ) are major problem in corn farming. These deficiencies are mainly caused by soil low fertility, e.g. in the Cerrado biome (savannah), nutrient harvest exports, highlevel phosphate application, and non-incorporated limestone in no-tillage systems (overliming), which increases $\mathrm{Zn}$ insolubilization. For these reasons, $\mathrm{Zn}$ shows the highest grain-yield responses in corn crops in Brazilian soils.

Zinc is one of the most important micronutrients for growth and development of higher plants. This nutrient is involved in several vital physiological processes such as protein synthesis, energy production, and membrane integrity maintenance (HANSCH; MENDEL, 2009; DRISSI et al., 2017). Among its basic functions in plants, $\mathrm{Zn}$ compounds many enzymes such as dehydrogenases, proteinases, peptidases, and phosphohydrolases, besides being related to carbohydrate, protein, and phosphate metabolism and auxin, RNA, and, ribosome formation (MARSCHNER, 2012; OJEDA-BARRIOS et al., 2014). Moreover, it is involved in phenol metabolism, starch formation, cell growth and multiplication, and pollen fertility (MARSCHNER, 2012; DAVARPANAH et al., 2016). Therefore, since corn plants are sensitive to Zn deficiency (GUPTA et al., 2008; DRISSI et al., 2017), it has become a worldwide constraint in such crops (CAKMAK, 2008).

Likewise, B is also related to several plant physiological processes such as sugar transport, cell wall synthesis, lignification, cell wall structuring, carbohydrate metabolism, RNA metabolism, respiration, indole acetic acid (IAA) metabolism, phenol metabolism, ascorbate metabolism, and plasma membrane integrity (BELL; DELL, 2008; SONGKHUM et al., 2018), as well as pollen grain germination and tube elongation. Also, this element is indirectly responsible for activation of dehydrogenase enzymes, sugar translocation, nucleic acids, and plant hormones (EL-SHEIKH et al., 2007; MARSCHNER, 2012).

Hosseini et al. (2007) proved significant effects of $\mathrm{B} \times \mathrm{Zn}$ interaction on many plant biochemical and physiological processes. Nutritional interactions interfere with plant mineral composition, whereby an excess of one element can stimulate or inhibit absorption of others. Such relationships vary widely and can occur inside the cells or in the rhizosphere (MENGEL; KIRKBY, 2001). Both B and Zn are essential to improve ATPase functioning, which is essential for the use of metabolic energy (ATP). Furthermore, the absence of $\mathrm{B}$ may reduce $\mathrm{Zn}$ efficiency in plants and vice-versa (DAVARPANAH et al., 2016; SONGKHUM et al., 2018).

According to Tavallali (2017), adverse effects of $\mathrm{B}$ deficiency and toxicity in pistachio (Pistacia vera L. cv. Badami) seedlings are alleviated by increasing $\mathrm{Zn}$ levels up to $10 \mathrm{mg} \mathrm{kg}{ }^{-1}$ soil. Also, at proper concentrations, $\mathrm{B}$ and $\mathrm{Zn}$ interact synergistically. Understanding when this happens may provide relevant results and hence increase plant growth and productivity. In this line of thought, the residual effect of $\mathrm{B}$ and $\mathrm{Zn}$ fertilization on fall corn crops should also be investigated. Besides that, new corn hybrids are usually more productive and nutrientdemanding, so there is also a need to investigate these modern hybrids.

In Brazilian Cerrado soils, B and Zn deficiencies are common, mainly where high levels of phosphorus have been applied, which leads to $\mathrm{Zn}$ deficiency. Moreover, it is still debated whether $\mathrm{B}$ and $\mathrm{Zn}$ interaction has a synergistic or antagonistic effect on their respective absorption from the soil. Thus, this study aimed to evaluate the effect of B fertilization, with or without $\mathrm{Zn}$, on corn nutritional status and grain yield during the spring season, in addition to the residual effect of such fertilizations on fall corn crop grown on a boron-deficient soil of Cerrado biome. 


\section{Materials and Methods}

\section{Geographical location and management history}

Spring-summer and fall corn crops were grown in the same experimental area, which belongs to the Faculty of Engineering at UNESP, located in Selvíria-MS, Brazil. The area is at an altitude of 335 $\mathrm{m}$ above sea level, and average annual temperature, rainfall, and humidity are $23.5{ }^{\circ} \mathrm{C}, 1,370 \mathrm{~mm}$, and $70-80 \%$, respectively. The soil is classified as a dystrophic red Latosol "Latossolo Vermelho Distrófico" with clayey texture (Oxisol), according to Embrapa (2013). The area has been grown with annual crops for over 27 years, of which the last eight years have been under no-tillage system with the last year of fallow. Figure 1 shows the climatic conditions during both experiments of springsummer and fall corn crops.

Figure 1. Rainfall, air relative humidity and maximum, average and minimum temperatures obtained from the weather station located in the Education and Research Farm of FE / UNESP during the maize cultivation in the period December 2013 to April 2014 (A) and December 2014 to April 2015 (B).
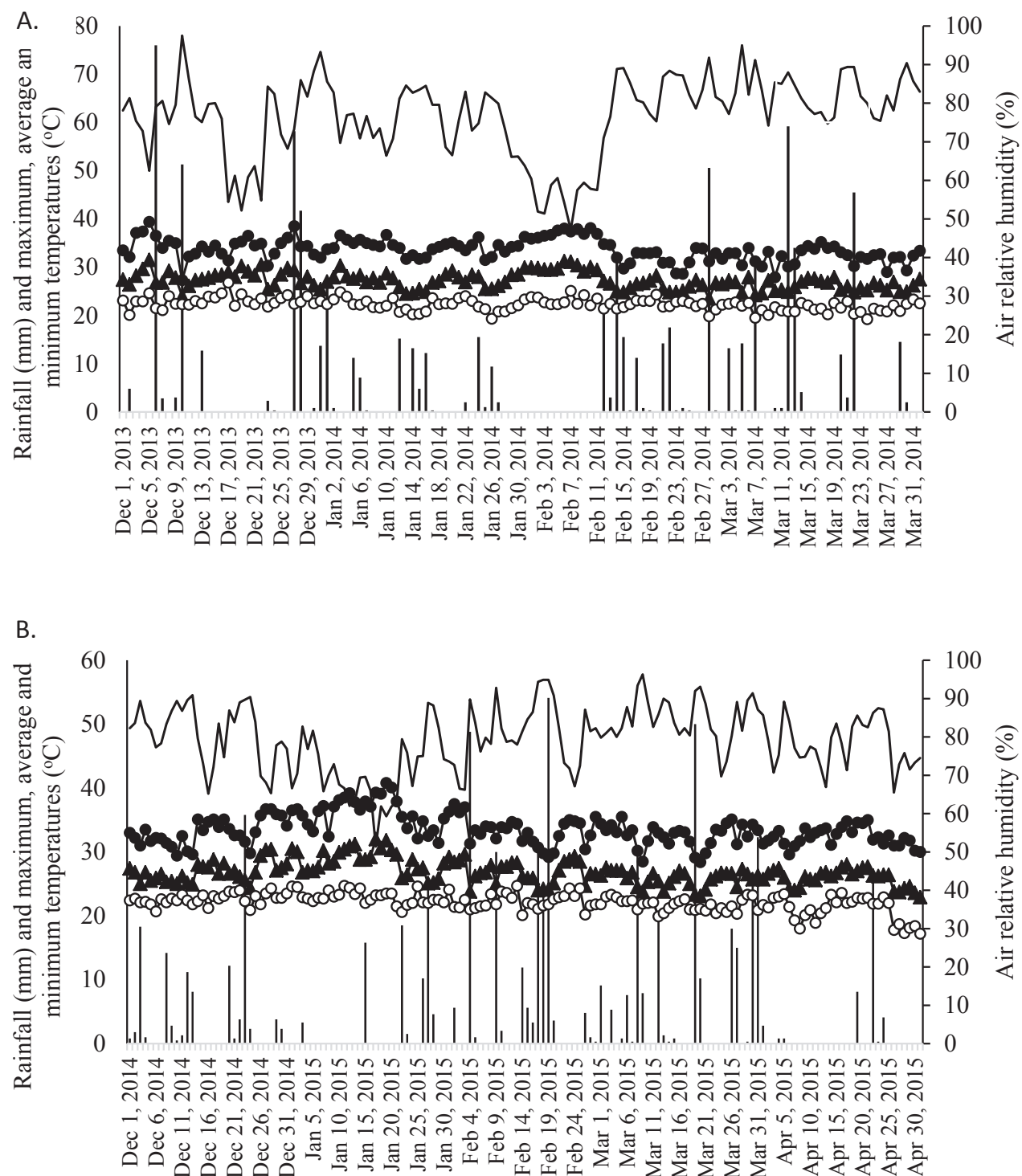

Rainfall $\longrightarrow$ Average T. $\longrightarrow$ Maximum T. $\multimap-$ Minimum T. $\longrightarrow$ Air relative humidity 


\section{Experimental design}

A randomized block experimental design with four replications was adopted, under a $2 \times 5$ factorial arrangement, consisting of application (or lack thereof) of $2 \mathrm{~kg} \mathrm{ha}^{-1} \mathrm{Zn}$ (in the form of zinc sulfate) and five $\mathrm{B}$ rates $\left(0,1,2,3\right.$, and $4 \mathrm{~kg} \mathrm{ha}^{-1}$, in the form of boric acid). Treatments were applied to the soil at seeding and about $0.10 \mathrm{~m}$ apart from corn rows. Plots were 5-m long with six rows spaced $0.45 \mathrm{~m}$ apart. The useful area of plots consisted of the four central rows, excluding $0.5 \mathrm{~m}$ from the edges.

\section{Trial establishment and management}

The soil chemical attributes in the arable layer $(0-0.20 \mathrm{~m})$ were determined before the experiment, following the method proposed by Raij et al. (2001) (Table 1). Based on this soil analysis and corn requirements, all the treatments were fertilized at planting with $400 \mathrm{~kg} \mathrm{ha}^{-1}$ of the 08-28-16 formula, which corresponded to 32,112 , and $64 \mathrm{~kg} \mathrm{ha}^{-1}$ of $\mathrm{N}$, $\mathrm{P}_{2} \mathrm{O}_{5}$, and $\mathrm{K}_{2} \mathrm{O}$, respectively. In both seasons, corn crops were conducted under no-tillage system.

Table 1. Soil chemical attributes in 0-0.20 m layer, before the implementation of the experiment.

\begin{tabular}{ll}
\hline \multicolumn{1}{c}{ Soil chemical attributes } & $0-0.20 \mathrm{~m}$ layer \\
\hline $\mathrm{P}($ resin) & $10 \mathrm{mg} \mathrm{dm}^{-3}$ \\
$\mathrm{~S}\left(\mathrm{SO}_{4}\right)$ & $5 \mathrm{mg} \mathrm{dm}^{-3}$ \\
Organic matter & $22 \mathrm{~g} \mathrm{dm}^{-3}$ \\
$\mathrm{pH}\left(\mathrm{CaCl}_{2}\right)$ & 5.3 \\
$\mathrm{~K}$ & $2.4 \mathrm{mmol}_{\mathrm{c}} \mathrm{dm}^{-3}$ \\
$\mathrm{Ca}$ & $21.0 \mathrm{mmol}_{\mathrm{c}} \mathrm{dm}^{-3}$ \\
$\mathrm{Mg}$ & $18.0 \mathrm{mmol}_{\mathrm{c}} \mathrm{dm}^{-3}$ \\
$\mathrm{H}+\mathrm{Al}$ & $28.0 \mathrm{mmol}_{\mathrm{c}} \mathrm{dm}^{-3}$ \\
$\mathrm{~B}$ (hot water) & $0.16 \mathrm{mg} \mathrm{dm}^{-3}$ \\
$\mathrm{Cu}$ (DTPA) & $3.2 \mathrm{mg} \mathrm{dm}^{-3}$ \\
$\mathrm{Fe}$ (DTPA) & $22.0 \mathrm{mg} \mathrm{dm}^{-3}$ \\
$\mathrm{Mn}$ (DTPA) & $24.2 \mathrm{mg} \mathrm{dm}^{-3}$ \\
$\mathrm{Zn}$ (DTPA) & $1.2 \mathrm{mg} \mathrm{dm}^{-3}$ \\
$\mathrm{Cation}$ exchange capacity (pH 7.0) & $69.4 \mathrm{mmol}_{\mathrm{c}} \mathrm{dm}^{-3}$ \\
Base saturation (\%) & 60 \\
\hline
\end{tabular}

Both seasons were seeded with corn hybrid DKB 350 PRO (armyworm [Spodoptera frugiperda] resistant), using a shank-type seeder. Sowings were carried out on 12/04/13 and 04/15/14 by depositing 73,333 seeds ha ${ }^{-1}$. Plantlets emerged five days after seeding. Soil $\mathrm{B}$ and $\mathrm{Zn}$ applications were also performed manually on 12/04/13.

The herbicides tembotrione $\left(84 \mathrm{~g} \mathrm{ha}^{-1}\right.$ active ingredient [a.i.]) and atrazine (1,000 $\mathrm{g} \mathrm{ha}^{-1}$ a.i.) were applied at V2 corn stage (two fully expanded leaves), plus vegetable oil (720 $\mathrm{g} \mathrm{ha}^{-1}$ a.i.) as adjuvant. Neither pest nor disease management was necessary in either seasons. At V6 stage, nitrogen topdressing was performed (100 $\left.\mathrm{kg} \mathrm{N} \mathrm{ha}^{-1}\right)$ by broadcasting urea in between corn rows, without soil incorporation. Whenever necessary and after nitrogen fertilization, sprinkler irrigation was done, using a water depth of $13 \mathrm{~mm}$, from a center pivot system.

Corn hybrid, crop management, sowing fertilization, and nitrogen topdressing were the same in both spring-summer and fall crops of 2014. However, the residual effect of soil treatments (B rates, with or without $\mathrm{Zn}$ ) were evaluated, i.e., fall 
crop treatments were superimposed on the previous crop ones. Spring-summer and fall corn were harvested 112 and 122 days after plant emergence, respectively.

\section{Data collection}

For both corn crops, leaf concentrations of $\mathrm{N}, \mathrm{P}, \mathrm{K}, \mathrm{Ca}, \mathrm{Mg}, \mathrm{S}, \mathrm{B}, \mathrm{Cu}, \mathrm{Fe}, \mathrm{Mn}$, and $\mathrm{Zn}$ were determined as proposed by Malavolta et al. (1997). It consisted of collecting the middle third of 20 leaves of the main ear at female flowering, per plot, according to the method described by Cantarella et al. (1997). Grain yield was measured using ears from plants within the useful plot area. After mechanical threshing, grains were weighted, and data were transformed into $\mathrm{kg} \mathrm{ha}^{-1}$ at $13 \%$ moisture. After harvesting both crops, $\mathrm{B}$ and $\mathrm{Zn}$ contents in the soil (0-0.20 m layer) were also analyzed using a soil auger, and sampling was carried out at five points per plot, where both elements had been applied.

\section{Statistical analysis}

Data were submitted to analysis of variance (F-test). When significant ( $p \leq 0.01$ and $p \leq 0.05)$, means were compared by the Tukey's test $(p \leq 0.05)$ for $\mathrm{Zn}$ application (with or without) and adjusted to polynomial regression models for $B$ rates, using the SISVAR software (FERREIRA, 2011).

\section{Results and Discussion}

\section{Leaf macronutrient concentrations}

Leaf macronutrient concentrations of springsummer corn were not influenced by B rates or $\mathrm{Zn}$ fertilization applied to the soil (Table 2). Of these nutrients, only $\mathrm{S}$ was influenced by $\mathrm{Zn}$ fertilization, with higher values, likely because the applied source was zinc sulfate (Table 2). Jamami et al. (2006) evaluated different $\mathrm{Zn}$ rates applied to the soil and did not observe an effect on leaf macronutrient concentrations in corn. Conversely, Adiloglu and Adiloglu (2006) assessed the effect of increasing $\mathrm{B}$ rates $\left(0,10\right.$, and $\left.20 \mathrm{mg} \mathrm{kg}^{-1}\right)$ and $\mathrm{Zn}(0$ and 10 $\mathrm{mg} \mathrm{kg}^{-1}$ ) on corn grown in a $\mathrm{Zn}$-deficient soil; they found that the concentrations of $\mathrm{N}, \mathrm{P}$, and $\mathrm{K}$ in plants increased with B and $\mathrm{Zn}$ applications.

When compared to no application, $\mathrm{Zn}$ showed a residual effect in fall corn only on $\mathrm{N}$ leaf concentration (Table 3). Such a high concentration might have occurred due to the equilibrium between mineral and protein $\mathrm{N}$, and the role of $\mathrm{Zn}$ in processes where $\mathrm{N}$ is essential such as enzyme activation, protein synthesis, and cell division (MANZEKE et al., 2014; DRISSI et al., 2017). However, if protein synthesis was reduced, $\mathrm{N}$ concentration could remain the same since $\mathrm{N}-\mathrm{NO}_{3}{ }^{-}$or $\mathrm{N}_{-} \mathrm{NH}_{4}^{+}$would show higher concentrations.

Regarding the residual effect of $\mathrm{B}$ rates on fall corn, no isolated effect was observed on macronutrient concentrations (Table 3). Yet, when B fertilization was associated with $\mathrm{Zn}$ application, leaf $\mathrm{Ca}$ and $\mathrm{Mg}$ concentrations increased up to $\mathrm{B}$ rates of 1.51 and $1.20 \mathrm{~kg} \mathrm{ha}^{-1}$, respectively (Figures 2A, B). According to Marschner (2012), the concentrations of $\mathrm{Ca}$ and $\mathrm{B}$ are correlated in plant tissues, which might explain B nutrition status of plants in the present study. Despite adequate $\mathrm{Ca}$ supply in roots, this element could not be effectively used in the absence of B (SHAMS et al., 2012). Boron enabled plants to absorb more $\mathrm{Ca}$ in a given time or use it more efficiently in their metabolism after absorbed (GANMORE-NEUMANN; DAVIDOV, 1993). Boron deficiency inhibits $\mathrm{Ca}$ translocation and induces abnormal changes in its metabolism in the cell wall (YAMAUCHI et al., 1986). Root elongation also depends on cell turgor pressure and hence, on the stability of the cell wall (SHAMS et al., 2012). Both B and Ca are required for the stability of the pectin fraction in cell walls (KOBAYASHI et al., 1999). 
Table 2. Leaf concentrations of nitrogen $(\mathrm{N})$, phosphorus $(\mathrm{P})$, potassium $(\mathrm{K})$, calcium $(\mathrm{Ca})$, magnesium $(\mathrm{Mg})$ and sulfur (S) of spring/summer corn, affected by boron rates applied to the soil, with and without fertilization with zinc in the soil. Selvíria - MS, Brazil.

\begin{tabular}{ccccccc}
\hline & $\mathrm{N}$ & $\mathrm{P}$ & $\mathrm{K}$ & $\mathrm{Ca}$ & $\mathrm{Mg}$ & $\mathrm{S}$ \\
\hline & & $---{ }^{2}-{ }_{-}$ & - & \\
\hline With zinc & $27.08 \mathrm{a}$ & $3.42 \mathrm{a}$ & $27.06 \mathrm{a}$ & $3.86 \mathrm{a}$ & $1.69 \mathrm{a}$ & $2.20 \mathrm{a}$ \\
Without zinc & $27.28 \mathrm{a}$ & $3.52 \mathrm{a}$ & $26.17 \mathrm{a}$ & $4.15 \mathrm{a}$ & $1.79 \mathrm{a}$ & $1.88 \mathrm{~b}$ \\
\hline H.S.D. $(5 \%)$ & 1.79 & 0.20 & 1.40 & 0.57 & 0.30 & 0.03 \\
\hline B rates $\left(\mathrm{kg} \mathrm{ha}^{-1}\right)$ & & & & & & \\
\hline 0 & 28.48 & 3.43 & 26.35 & 4.05 & 1.77 & 2.03 \\
1 & 27.45 & 3.52 & 26.23 & 4.15 & 1.80 & 2.03 \\
2 & 26.48 & 3.50 & 26.18 & 3.90 & 1.75 & 2.08 \\
3 & 26.60 & 3.47 & 26.71 & 4.13 & 1.85 & 2.02 \\
4 & 26.88 & 3.43 & 27.60 & 3.80 & 1.55 & 2.03 \\
\hline Overall mean & 27.18 & 3.47 & 26.62 & 4.00 & 1.74 & 2.04 \\
\hline C.V. (\%) & 8.61 & 7.41 & 6.88 & 17.48 & 22.52 & 19.37 \\
\hline
\end{tabular}

Means followed by identical letters in the column are not different from one another by Tukey test at the $5 \%$ probability level.

Table 3. Leaf concentrations of nitrogen $(\mathrm{N})$, phosphorus $(\mathrm{P})$, potassium $(\mathrm{K})$, calcium $(\mathrm{Ca})$, magnesium $(\mathrm{Mg})$ and sulfur $(\mathrm{S})$ of fall corn, affected by residual of boron rates applied to the soil, with and without fertilization with zinc in the soil. Selvíria - MS, Brazil.

\begin{tabular}{|c|c|c|c|c|c|c|}
\hline & $\mathrm{N}$ & $\mathrm{P}$ & $\mathrm{K}$ & $\mathrm{Ca}$ & $\mathrm{Mg}$ & $\mathrm{S}$ \\
\hline & \multicolumn{6}{|c|}{---------------------------------------( } \\
\hline With zinc & $28.57 \mathrm{a}$ & $4.07 \mathrm{a}$ & $25.10 \mathrm{a}$ & $4.56 \mathrm{a}$ & $3.31 \mathrm{a}$ & $2.59 \mathrm{a}$ \\
\hline Without zinc & $27.25 \mathrm{~b}$ & $4.11 \mathrm{a}$ & $26.54 \mathrm{a}$ & $4.57 \mathrm{a}$ & $3.28 \mathrm{a}$ & $2.64 \mathrm{a}$ \\
\hline H.S.D. (5\%) & 1.08 & 0.16 & 1.82 & 0.65 & 0.40 & 0.27 \\
\hline \multicolumn{7}{|l|}{$\mathrm{B}$ rates $\left(\mathrm{kg} \mathrm{ha}^{-1}\right)$} \\
\hline 0 & 27.48 & 4.15 & 26.07 & 4.68 & 3.33 & 2.51 \\
\hline 1 & 29.12 & 4.10 & 25.15 & 4.86 & 3.55 & 2.55 \\
\hline 2 & 26.25 & 4.15 & 25.08 & 5.35 & 3.63 & 2.73 \\
\hline 3 & 28.24 & 4.13 & 27.58 & 4.30 & 3.11 & 2.61 \\
\hline 4 & 28.47 & 3.93 & 25.22 & 3.63 & 2.85 & 2.67 \\
\hline Overall mean & 27.91 & 4.09 & 25.82 & 4.60 & 3.30 & 2.61 \\
\hline C.V. $(\%)$ & 5.03 & 5.00 & 9.18 & 18.48 & 15.94 & 13.54 \\
\hline
\end{tabular}

Means followed by identical letters in the column are not different from one another by Tukey test at the $5 \%$ probability level.

It is noteworthy that, both in spring-summer and fall crops (Table 2 and 3), average leaf macronutrient concentrations were within the adequate ranges suggested by Cantarella et al. (1997), which should be $27.0-35.0,2.0-4.0,17.0-35.0,2.5-8.0,1.5-5.0$, and 1.5-3.0 $\mathrm{g} \mathrm{kg}^{-1}$ for $\mathrm{N}, \mathrm{P}, \mathrm{K}, \mathrm{Ca}, \mathrm{Mg}$, and $\mathrm{S}$, respectively. 
Figure 2. Interaction between $\mathrm{B}$ rates and $\mathrm{Zn}$ application for $\mathrm{Ca}$ leaf concentration in fall crop (A); interaction between $\mathrm{B}$ rates and $\mathrm{Zn}$ application for $\mathrm{Mg}$ leaf concentration in fall crop (B); Cu leaf concentration in spring/summer crop as a function of B rates (C); Mn leaf concentration in spring/summer crop as a function of B rates (D); interaction between $\mathrm{B}$ rates and $\mathrm{Zn}$ application for B leaf concentration in spring/summer crop (E); interaction between $\mathrm{B}$ rates and $\mathrm{Zn}$ application for $\mathrm{Zn}$ leaf concentration in spring/summer crop $(\mathrm{F})$. The letters correspond to a significant difference at 5\% probability level $(p \leq 0.05)$. ** and *: significant at $p<0.01$ and $p<0.05$, respectively. L.S.D. (low significant difference $)=1.45(\mathrm{~A}), 0.90(\mathrm{~B}), 0.98(\mathrm{E})$ and $1.43(\mathrm{~F})$.

A.

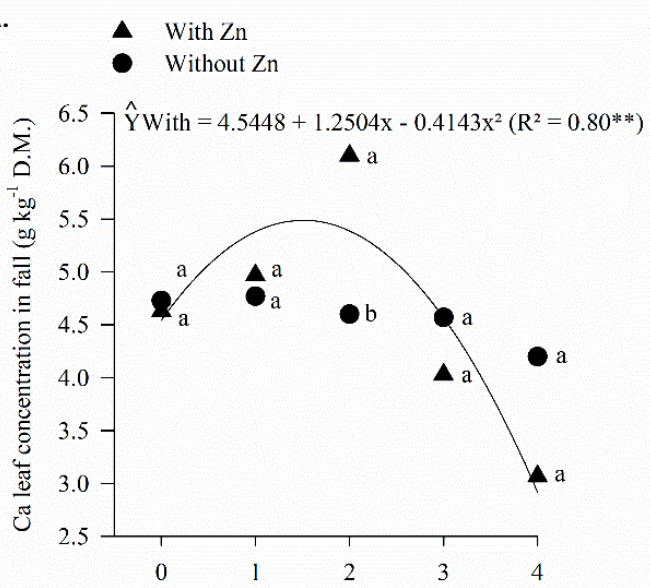

C.

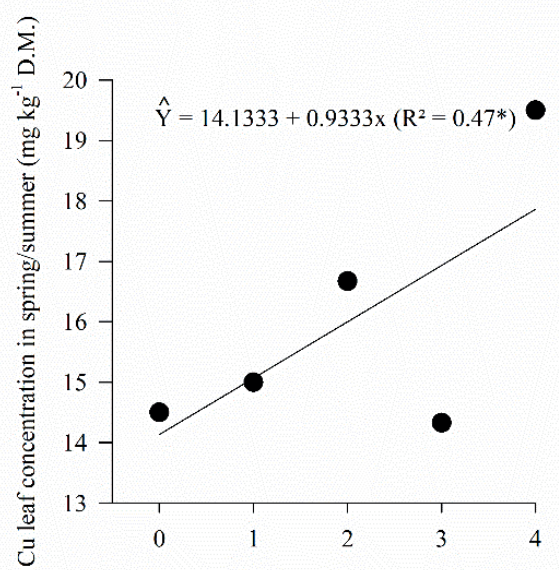

E.

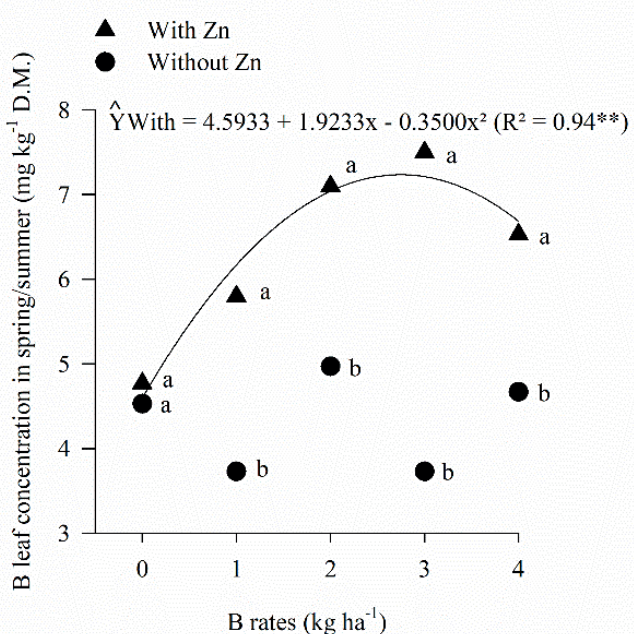

B.

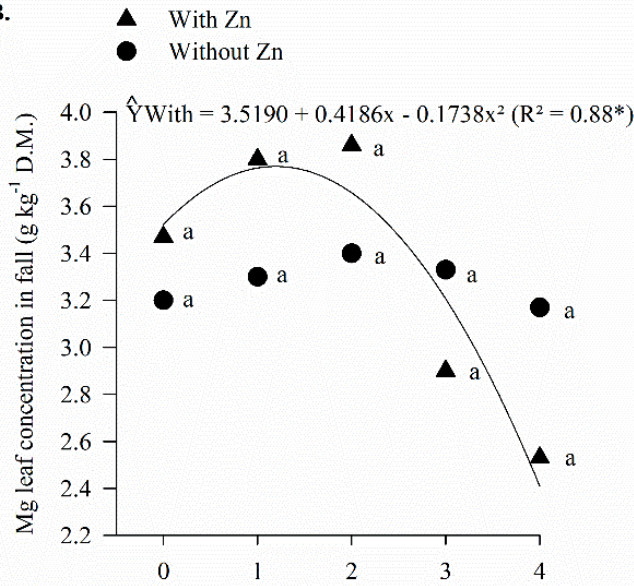

D.
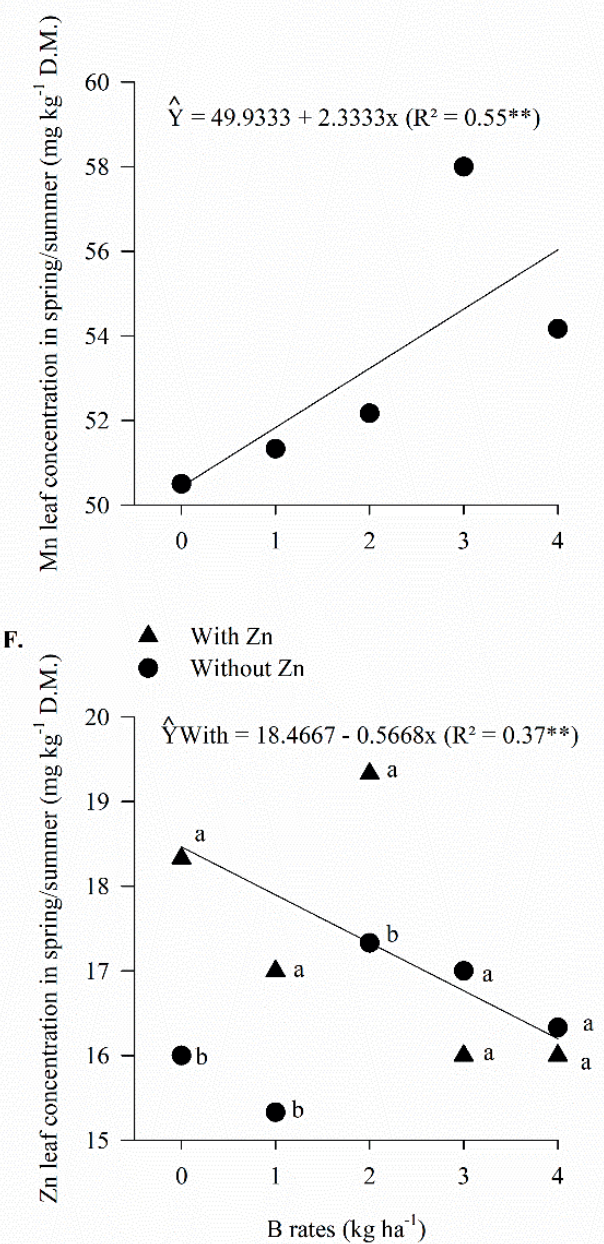
Leaf micronutrient concentrations and corn grain yield

Despite the known antagonism by competitive inhibition of $\mathrm{Zn}$ with $\mathrm{Cu}, \mathrm{Fe}$, and $\mathrm{Mn}$, the addition of $\mathrm{Zn}$ had no influence on the leaf concentrations of these cationic micronutrients, neither in springsummer nor fall corn plants (Tables 4 and 5). This result may be due to the low $\mathrm{Zn}$ rate applied in this study $\left(2 \mathrm{~kg} \mathrm{ha}^{-1}\right)$. Increasing B rates provided a linear increase in the leaf concentrations of $\mathrm{Cu}$ and $\mathrm{Mn}$ in spring-summer corn (Figures 2C, D). Conversely, studying the effect of increasing $\mathrm{B}$ and $\mathrm{Zn}$ rates in corn plant grown on $\mathrm{Zn}$ deficient soil, Adiloglu and Adiloglu (2006) verified that the concentrations of $\mathrm{Cu}, \mathrm{Zn}$, and $\mathrm{Mn}$ increased but those of Fe were adversely affected by $\mathrm{Zn}$ application, whereas B application affected them positively. By contrast, Fageria et al. (2002) reported that high B inputs resulted in low $\mathrm{Zn}, \mathrm{Fe}$, and $\mathrm{Mn}$ absorptions while increased $\mathrm{Cu}$ intake.

Table 4. Leaf concentrations of boron $(\mathrm{B})$, copper $(\mathrm{Cu})$, iron $(\mathrm{Fe})$, manganese $(\mathrm{Mn})$ and zinc $(\mathrm{Zn})$ and grain yield of spring/summer corn, affected by boron rates applied to the soil, with and without fertilization with zinc in the soil. Selvíria - MS, Brazil.

\begin{tabular}{|c|c|c|c|c|c|c|}
\hline & $\mathrm{B}$ & $\mathrm{Cu}$ & $\mathrm{Fe}$ & $\mathrm{Mn}$ & $\mathrm{Zn}$ & Grain yield \\
\hline & \multicolumn{5}{|c|}{ 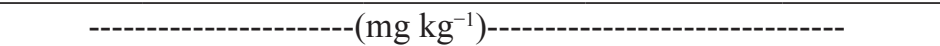 } & $\left(\mathrm{kg} \mathrm{ha}^{-1}\right)$ \\
\hline With zinc & 6.34 & $16.53 \mathrm{a}$ & $128.73 \mathrm{a}$ & $54.60 \mathrm{a}$ & 17.33 & $6547 \mathrm{a}$ \\
\hline Without zinc & 4.32 & $15.47 \mathrm{a}$ & $139.20 \mathrm{a}$ & $51.87 \mathrm{a}$ & 16.40 & $6431 \mathrm{a}$ \\
\hline H.S.D. $(5 \%)$ & 0.44 & 1.99 & 12.98 & 4.64 & 0.64 & 464 \\
\hline \multicolumn{7}{|l|}{$\mathrm{B}$ rates $\left(\mathrm{kg} \mathrm{ha}^{-1}\right)$} \\
\hline 0 & 4.65 & $14.50^{(1)}$ & 125.50 & $50.50^{(2)}$ & 17.17 & 6095 \\
\hline 1 & 4.77 & 15.00 & 132.17 & 51.33 & 16.17 & 6673 \\
\hline 2 & 6.03 & 16.67 & 131.83 & 52.17 & 18.33 & 6631 \\
\hline 3 & 5.61 & 14.33 & 138.67 & 58.00 & 16.50 & 7032 \\
\hline 4 & 5.60 & 19.50 & 141.67 & 54.17 & 16.17 & 6316 \\
\hline Overall mean & 5.33 & 16.00 & 133.97 & 53.23 & 16.87 & 6490 \\
\hline C.V. $(\%)$ & 10.75 & 16.19 & 12.63 & 11.37 & 4.93 & 11.71 \\
\hline
\end{tabular}

Means followed by identical letters in the column are not different from one another by Tukey test at the $5 \%$ probability level.

Table 5. Leaf concentrations of boron $(\mathrm{B})$, copper $(\mathrm{Cu})$, iron $(\mathrm{Fe})$, manganese $(\mathrm{Mn})$ and zinc $(\mathrm{Zn})$ and grain yield of fall corn, affected by residual of boron rates applied to the soil, with and without fertilization with zinc in the soil Selvíria - MS, Brazil.

\begin{tabular}{|c|c|c|c|c|c|c|}
\hline & $\mathrm{B}$ & $\mathrm{Cu}$ & $\mathrm{Fe}$ & $\mathrm{Mn}$ & $\mathrm{Zn}$ & Grain yield \\
\hline & \multicolumn{5}{|c|}{ 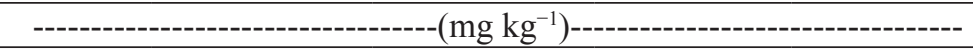 } & $\left(\mathrm{kg} \mathrm{ha}^{-1}\right)$ \\
\hline With zinc & 6.00 & 15.33 & $204.73 \mathrm{a}$ & $38.67 \mathrm{a}$ & $20.20 \mathrm{a}$ & $5279 \mathrm{a}$ \\
\hline Without zinc & 6.20 & 15.53 & $208.33 \mathrm{a}$ & $39.87 \mathrm{a}$ & $19.93 \mathrm{a}$ & $5070 \mathrm{a}$ \\
\hline H.S.D. $(5 \%)$ & 1.97 & 3.18 & 18.21 & 3.98 & 1.13 & 523 \\
\hline \multicolumn{7}{|l|}{$\mathrm{B}$ rates $\left(\mathrm{kg} \mathrm{ha}^{-1}\right)$} \\
\hline 0 & 4.00 & 14.67 & 200.67 & 36.33 & $19.50^{(1)}$ & 5202 \\
\hline 1 & 4.67 & 16.00 & 213.00 & 38.33 & 20.67 & 5788 \\
\hline 2 & 6.00 & 12.33 & 221.50 & 42.17 & 21.83 & 5112 \\
\hline 3 & 6.67 & 13.00 & 209.85 & 39.50 & 19.50 & 4816 \\
\hline 4 & 9.17 & 21.17 & 188.83 & 40.00 & 18.33 & 4954 \\
\hline Overall mean & 6.10 & 15.43 & 206.53 & 39.27 & 20.07 & 5174 \\
\hline C.V. $(\%)$ & 25.59 & 26.86 & 11.50 & 13.21 & 7.31 & 15.59 \\
\hline
\end{tabular}

Means followed by identical letters in the column are not different from one another by Tukey test at the $5 \%$ probability level. 
Root elongation depends on the stability of cell walls (Shams et al., 2012). As B increases the stability of pectin fraction, this micronutrient may assist in root elongation, increasing the volume of soil explored. Hence, the absorption of some nutrients such as $\mathrm{Cu}$ and $\mathrm{Mn}$, which are highly available in tropical acid soils, may increase, as well as their concentrations in foliar tissues. Such explanation may clarify the results observed in this study.

A significant interaction was found between $\mathrm{Zn}$ fertilization and $\mathrm{B}$ rates for the leaf $\mathrm{B}$ and $\mathrm{Zn}$ concentrations of spring-summer corn. Leaf B concentrations increased up to the rate applied of $2.75 \mathrm{~kg} \mathrm{~B} \mathrm{ha}^{-1}$, only when $\mathrm{Zn}$ was applied (Figures 2E, F). Leaf B concentration was higher when $\mathrm{Zn}$ fertilization was associated with $B$ rates of 1, 2, 3, and $4 \mathrm{~kg} \mathrm{ha}^{-1}$, thus indicating a synergistic effect of the two elements. An adequate $\mathrm{Zn}$ concentration prevents plants from absorbing and accumulating excess $\mathrm{B}$ in leaves by increasing membrane integrity of root cells (TAVALLALI, 2017). Leaf Zn concentrations were also influenced by increasing $\mathrm{B}$ rates, only when $\mathrm{Zn}$ was applied, thus fitting a decreasing linear equation. Leaf $\mathrm{Zn}$ concentration was higher when $\mathrm{Zn}$ fertilization was associated with $\mathrm{B}$ rates of 1 and $2 \mathrm{~kg} \mathrm{ha}^{-1}$ and without $\mathrm{B}$ application $\left(0 \mathrm{~kg} \mathrm{ha}^{-1}\right)$.

According to Tavallali (2017), the adverse effects of B deficiency and toxicity on pistachio (Pistacia vera L. cv. Badami) seedlings were alleviated by increasing $\mathrm{Zn}$ levels up to $10 \mathrm{mg} \mathrm{kg}^{-1}$ soil. Also, if B and $\mathrm{Zn}$ are adequate, synergism can be observed between both nutrients, as seen in the present research. Suitable amounts of B may speed up the effects of $\mathrm{Zn}$ by raising plant dry weight, photosynthesis, carbonic anhydrase activity, and chlorophyll contents (TAVALLALI, 2017).

Analyzing the statistical breakdown of $\mathrm{Zn}$ application into the B rates, except for control, leaf $\mathrm{B}$ concentrations were higher at all the $\mathrm{B}$ rates when
Zn was applied (Figure 2E). This result points out a synergistic effect of Zn on B absorption by corn plants in clayey soil under B deficiency. Both B and Zn are essential to the optimal functioning of ATPase, the absence of one reduces the efficiency of the other (DAVARPANAH et al., 2016; SONGKHUM et al., 2018). In a study on corn grown in Oxisol, Jamami et al. (2006) evaluated plant response to different rates of $\mathrm{B}\left(0,1\right.$, and $\left.2 \mathrm{~kg} \mathrm{ha}^{-1}\right)$ and $\mathrm{Zn}(0,2$, and 4 $\mathrm{kg} \mathrm{ha}^{-1}$ ) applied in planting furrow; these authors found neither increases in leaf concentrations of both nutrients nor interaction between their rates.

Boron doses showed residual effects only on $\mathrm{Zn}$ concentrations in fall corn leaves, with a quadratic fit and maximum values at $1.76 \mathrm{~kg} \mathrm{~B} \mathrm{ha}^{-1}$ (Figure 3A). Again, synergism was evidenced by combination of these micronutrients. Likewise, Sinha et al. (2000) observed a synergistic interaction between $\mathrm{Zn}$ and B in black mustard (Brassica nigra) when both nutrients were either in low (positive effect) or excess (adverse effect) supply.

The interaction between $\mathrm{Zn}$ fertilization and $\mathrm{B}$ rates influenced significantly leaf $\mathrm{B}$ and $\mathrm{Cu}$ concentrations. When associated with $\mathrm{Zn}$, leaf $\mathrm{B}$ and $\mathrm{Cu}$ concentrations increased linearly with increasing $\mathrm{B}$ fertilization levels (Figures 3B, C), among which the highest $\mathrm{B}$ level $\left(4 \mathrm{~kg} \mathrm{ha}^{-1}\right)$ provided the largest leaf B and $\mathrm{Cu}$ concentrations. Gupta (1993) reported that high $\mathrm{B}$ rates result in low $\mathrm{Zn}, \mathrm{Fe}$, and $\mathrm{Mn}$ absorptions and increased $\mathrm{Cu}$ absorption by plants. Gunesh et al. (2000) studied increasing rates of $\mathrm{B}$ and $\mathrm{Zn}$ on tomato crops and verified increased B concentrations in plants under no Znapplied conditions. According to these researchers, B toxicity may be prevented by $\mathrm{Zn}$ application to plants. However, unlike most of the studies on B and $\mathrm{Zn}$ interaction in plant nutrition, the present study was carried out in an initially B-deficient soil with medium acidity and clayey texture, which can explain the difference between the results. 
Figure 3. $\mathrm{Zn}$ leaf concentration in fall crop as a function of $\mathrm{B}$ rates (A); interaction between $\mathrm{B}$ rates and $\mathrm{Zn}$ application for $\mathrm{B}$ leaf concentration in fall crop (B); interaction between $\mathrm{B}$ rates and $\mathrm{Zn}$ application for $\mathrm{Cu}$ leaf concentration in fall crop (C); B content in soil in spring/summer crop as a function of B rates (D); Zn content in soil in spring/summer crop as a function of B rates (E). The letters correspond to a significant difference at $5 \%$ probability level $(p \leq 0.05)$. $* *$ and *: significant at $p<0.01$ and $p<0.05$, respectively. L.S.D. (low significant difference) $=2.68$ (B), and 7.11 (C).

A.

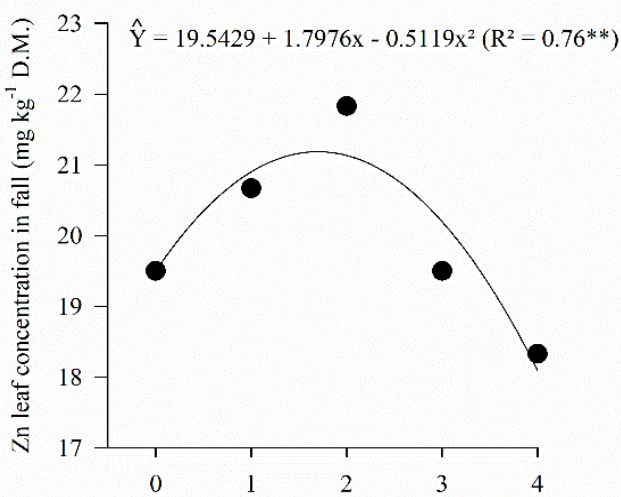

C.

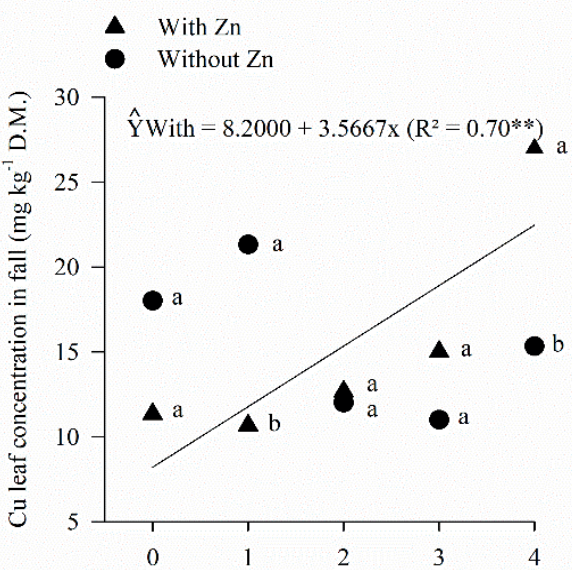

E.

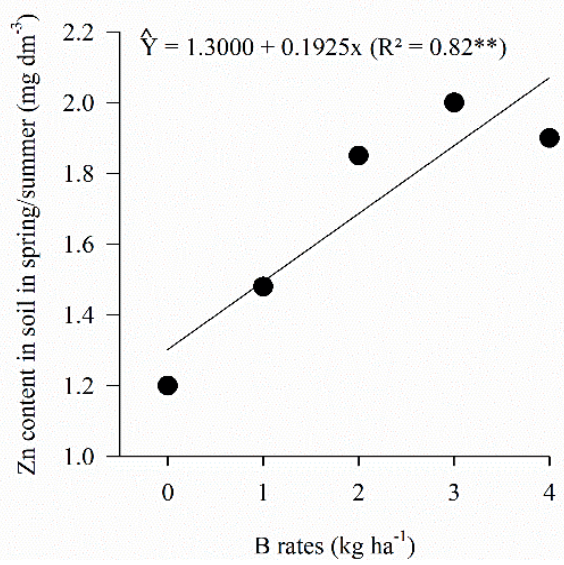

B.

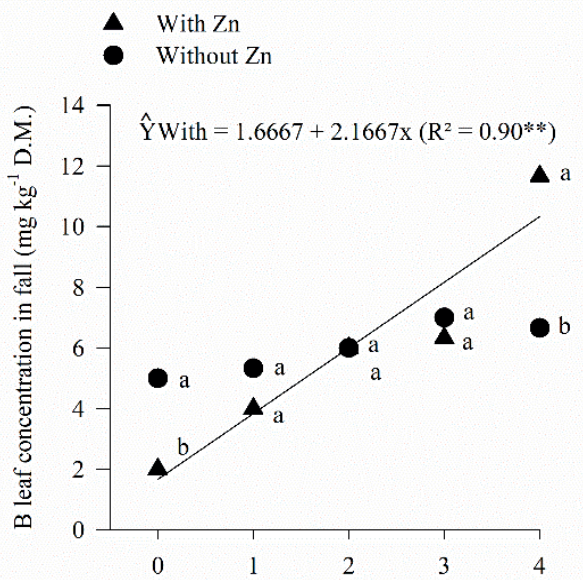

D.

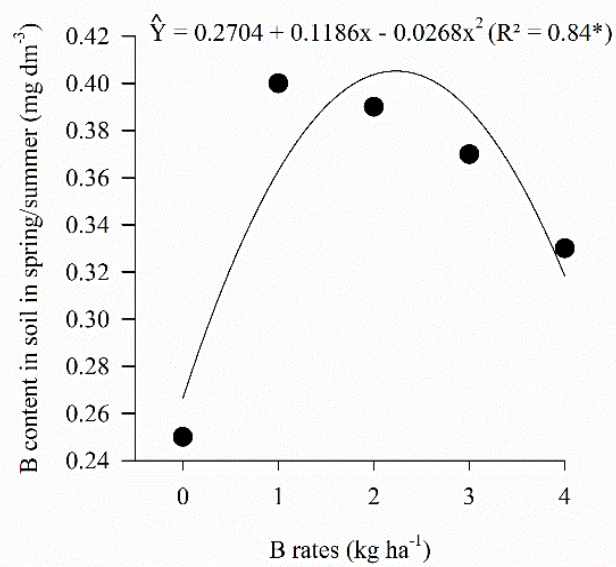


According to Cantarella et al.(1997), the adequate ranges of leaf $\mathrm{B}, \mathrm{Cu}, \mathrm{Fe}, \mathrm{Mn}$, and $\mathrm{Zn}$ concentrations for corn plants are 10-25, 6-20, 30-250, 20-200, and $15-100 \mathrm{mg} \mathrm{kg}^{-1}$, respectively; therefore, the average leaf concentrations of $\mathrm{Cu}, \mathrm{Fe}, \mathrm{Mn}$, and $\mathrm{Zn}$ found in both crops were adequate (Tables 4 and 5). Unlike these nutrients, leaf $\mathrm{B}$ concentrations remained below the acceptable range, even at higher $\mathrm{B}$ rates. However, neither deficiency nor toxicity symptoms were noted in plants, which can be explained by the low requirement of such corn hybrid for this element. Gupta (1993) stated that B concentrations in plant tissues may be related to several factors such as genetics, developmental stage, and environment (soil and climate).

Despite increases of 116 and $209 \mathrm{~kg} \mathrm{ha}^{-1}$ in spring-summer and fall grains, respectively, $\mathrm{Zn}$ fertilization had no influence on these crops (Tables 4 and 5). This can be attributed to the average $\mathrm{Zn}$ content $\left(1.2 \mathrm{mg} \mathrm{dm}^{-3}\right)$ available in the soil of the experimental area, which was enough for crop nutrition and development. For Fancelli and Dourado Neto (2000), the critical range is for this element is between 0.5 and $1.0 \mathrm{mg} \mathrm{kg}{ }^{-1}$. Besides that, the high clay content of the soil dramatically reduced $\mathrm{Zn}$ leaching from arable layer, enhancing its residual effect, which can explain the obtained results.

By contrast, Manzeke et al. (2014) found increases in corn yield after $\mathrm{Zn}$ application to the soil under deficiency conditions. Souza et al. (1998) found positive responses for corn grain yield to increasing $\mathrm{Zn}$ rates in planting furrows, but only until a rate of $5 \mathrm{~kg} \mathrm{ha}^{-1}$.

Increasing B rates did not significantly influence corn grain yield of both crops (Tables 4 and 5), despite the low soil $\mathrm{B}$ availability and the previously reported increased levels of $\mathrm{B}$ absorbed by corn when associated with $\mathrm{Zn}$ application. These results may be explained mainly by the low $\mathrm{B}$ requirement of the used corn hybrid, besides the high soil clay content, which could increase the adsorption of this element.

Trautmann et al. (2014) also did not find B influence on soybean grain yield, although other reports highlight the importance of $\mathrm{B}$ on reproductive development of crops (DEBNATH et al., 2011; MUHMOOD et al., 2014; BRUNES et al., 2015). Yet, Adiloglu and Adiloglu (2006) verified that shoot dry matter yield of corn plants grown in Zn-deficient soil decreased with B application, while increased with $\mathrm{Zn}$ application soil.

\section{Soil contents of born and zinc}

As for $\mathrm{B}$ and $\mathrm{Zn}$ in the soil after corn cultivation, contents were higher when $\mathrm{Zn}$ was applied, but only significant after spring-summer cultivation (Tables 6 and 7). These results explained the higher leaf $\mathrm{B}$ and $\mathrm{Zn}$ concentrations in spring-summer corn under $\mathrm{Zn}$ application (Table 4). Regarding the effect of $\mathrm{B}$ rates, a quadratic function was fitted, with concentrations of this nutrient in the soil increasing up to the rate of $2.21 \mathrm{~kg} \mathrm{~B} \mathrm{ha}^{-1}$ after spring-summer cropping (Figure 3D). These results partially support the increased leaf $\mathrm{B}$ concentration up to the rate of $2.75 \mathrm{~kg} \mathrm{~B} \mathrm{ha}^{-1}$ when $\mathrm{Zn}$ was applied to the soil (Table 4). Also, as a cation, Zn interacts with all plant nutrients in soil or absorbed by plants as anions, including $\mathrm{NO}_{3}{ }^{-}$(nitrate), $\mathrm{PO}_{4}{ }^{3-}$ (phosphate), $\mathrm{SO}_{4}^{2-}$ (sulphate), $\mathrm{Cl}^{-}$(chloride), $\mathrm{BO}_{3}^{3-}$ (borate), and $\mathrm{MoO}_{4}^{2-}$ (molybdate) (Prasad et al., 2016).

After spring-summer cropping, Zn soil content increased linearly as B rates were raised (Figure $3 \mathrm{E}$ ), whereas leaf $\mathrm{Zn}$ concentrations was only influenced by $\mathrm{B}$ rates if $\mathrm{Zn}$ was applied to the soil, with reductions observed at $B$ rates above $2 \mathrm{~kg} \mathrm{ha}^{-1}$ (Table 6). Yet, B fertilization had no residual effect on soil $\mathrm{B}$ and $\mathrm{Zn}$ contents, although the same trend has been detected after the first corn crop (Table 7). 
Table 6. Soil boron (B) and zinc (Zn) contents after cultivation of spring/summer corn, affected by boron rates applied to the soil, with and without fertilization with zinc in the soil. Selvíria - MS, Brazil.

\begin{tabular}{ccc}
\hline & Soil B content & Soil Zn content \\
\hline & $0.39 \mathrm{a}$ & $1.87 \mathrm{a}$ \\
With zinc & $0.31 \mathrm{~b}$ & $1.50 \mathrm{~b}$ \\
Without zinc & 0.07 & 0.25 \\
H.S.D. $(5 \%)$ & & \\
\hline B rates $\left(\mathrm{kg} \mathrm{ha}^{-1}\right)$ & $0.25^{(1)}$ & $1.20^{(2)}$ \\
1 & 0.40 & 1.48 \\
2 & 0.39 & 1.85 \\
3 & 0.37 & 2.00 \\
4 & 0.33 & 1.90 \\
\hline Overall mean & 0.38 & 1.68 \\
\hline C.V. $(\%)$ & 21.44 & 14.60
\end{tabular}

Means followed by identical letters in the column are not different from one another by Tukey test at the $5 \%$ probability level.

Table 7. Soil boron (B) and zinc ( $\mathrm{Zn}$ ) contents after cultivation of fall corn, affected by residual of boron rates applied to the soil, with and without fertilization with zinc in the soil. Selvíria - MS, Brazil.

\begin{tabular}{ccc}
\hline & Soil B content & Soil Zn content \\
\hline & $0.42 \mathrm{a}$ & $3.10 \mathrm{a}$ \\
With zinc & $0.32 \mathrm{a}$ & $2.42 \mathrm{a}$ \\
\hline Without zinc & 0.13 & 1.09 \\
\hline H.S.D. $(5 \%)$ & & \\
\hline B rates $\left(\mathrm{kg} \mathrm{ha}^{-1}\right)$ & 0.32 & 2.93 \\
0 & 0.42 & 2.85 \\
1 & 0.45 & 2.63 \\
2 & 0.33 & 2.53 \\
4 & 0.33 & 2.88 \\
\hline Overall mean & 0.37 & 2.76 \\
\hline C.V. $(\%)$ & 35.90 & 39.02 \\
\hline
\end{tabular}

Means followed by identical letters in the column are not different from one another by Tukey test at the $5 \%$ probability level.

Soil B contents after spring-summer and fall corn crops ( 0.21 to $\left.0.60 \mathrm{mg} \mathrm{dm}^{-3} \mathrm{~B}\right)$ are considered adequate according to Raij et al. (1997). Therefore, these findings may explain, in part, the lack of response in terms of grain yield to an increase in B rates.

Soil Zn contents increased considerably compared to those at the beginning of the experiment. These contents are deemed as high $\left(>1.2 \mathrm{mg} \mathrm{dm}^{-3}\right.$ Zn) according to Raij et al. (1997), being also higher if compared to those obtained by Ferreira et al. (2001), Jamami et al. (2006), and Prado et al. (2007), who found average and maximum values of 1.2 and $1.8 \mathrm{mg} \mathrm{Zn} \mathrm{dm}^{-3}$ soil (Oxisol).

Average B and $\mathrm{Zn}$ increments in the soil after corn cropping may be due to the supply of these micronutrients (treatments) and soil organic-matter mineralization since the area was cultivated under no-tillage system and irrigated. Soil-applied B and $\mathrm{Zn}$ had a synergistic effect on corn nutritional status at rates of up to $2 \mathrm{~kg} \mathrm{~B} \mathrm{ha}^{-1}$, with higher soil contents resulting from the interaction of these 
micronutrients. Zinc fertilization and increasing $B$ rates had no significant influence on grain yield for both spring-summer and fall corn crops, grown in a B-deficient and clayey soil in the Cerrado biome. Although both $\mathrm{Zn}$ and B promoted a slight increase in corn grain yield, and even under residual effect, we recommend an economic analysis before applying these micronutrients.

\section{Conclusions}

Zinc supplying increased leaf $\mathrm{N}$ contents in fall corn and $\mathrm{S}, \mathrm{B}$, and $\mathrm{Zn}$ contents in spring-summer corn. It also increased B and Zn levels in the soil after the first corn crop. Raising B rates led to a linear increase in leaf $\mathrm{Cu}$ and $\mathrm{Mn}$ contents of spring-summer corn and $\mathrm{B}$ contents up to the rate of $2.75 \mathrm{~kg} \mathrm{~B} \mathrm{ha}^{-1}$, only when $\mathrm{Zn}$ was applied. Yet, B rates higher than $2 \mathrm{~kg} \mathrm{ha}^{-1}$ decreased leaf $\mathrm{Zn}$ content of both spring-summer and fall corn crops. When associated to $\mathrm{Zn}$, B fertilization had a residual effect on fall corn, with a linear increase in leaf $\mathrm{B}$ and $\mathrm{Cu}$ concentrations, besides a positive effect on $\mathrm{Ca}$ and $\mathrm{Mg}$ when low B rates were used.

There is a synergistic effect between $\mathrm{B}$ and $\mathrm{Zn}$ applied to the soil on corn nutritional status up to B rates of $2 \mathrm{~kg} \mathrm{ha}^{-1}$, with higher soil contents resulting from the interaction thereof. Zinc fertilization and increasing B rates had no significant influence on grain yield both for spring-summer and fall corn plants, grown in a B-deficient and clayey soil in the Cerrado biome.

\section{References}

ADILOGLU, A.; ADILOGLU, S. The effect of boron (B) application on the growth and nutrient contents of maize in zinc ( $\mathrm{Zn})$ deficient soil. Bulgarian Journal of Agricultural Science, Sofia, v. 12, p. 387-392, 2006.

BELL, R. W.; DELL, B. Micronutrients for sustainable food, feed, fibre and bioenergy production. Paris: IFA International Fertilizer Industry Association, 2008. 195 p.
BRUNES, A. P.; OLIVEIRA, S. de; LEMES, E. S.; TAVARES, L. C.; GEHLING, V. M.; DIAS, L. W.; VILLELA, F. A. Boron fertilization on wheat seed production. Ciência Rural, Santa Maria, v. 45, n. 9, p. 1572-1578, 2015. DOI: 10.1590/0103-8478cr20131676

CAKMAK, I. Enrichment of cereal grains with zinc: agronomic or genetic biofortification? Plant and Soil, Dordrecht, v. 302 , n.1-2, p. 1-17, 2008. DOI: $10.1007 /$ s11104-007-9466-3

CANTARELLA, H.; RAIJ, B. VAN; CAMARGO, C.E.O. Cereals. In: RAIJ, B. VAN; CANTARELLA, H.; QUAGGIO, J. A.; FURLANI, A. M. C. Fertilizer and lime recommendation for the State of São Paulo, Brazil. Campinas: Instituto Agronômico de Campinas, 1997. $285 \mathrm{p}$.

DAVARPANAH, S.; TEHRANIFAR, A.; DAVARYNEJAD, G.; ABADÍA, J.; KHORASANI, R. Effects of foliar applications of zinc and boron nano-fertilizers on pomegranate (Punica granatum cv. Ardestani) fruit yield and quality. Scientia Horticulturae, Amsterdam, v. 210, p. 57-64, 2016. DOI: 10.1016/j. scienta.2016.07.003

DEBNATH, M. R.; JAHIRUDDIN, M.; RAHMAN, M. M.; HAQUE, M. A. Determining optimum rate of B application for higher yield of wheat in old Brahmaputra floodplain soil. Journal of the Bangladesh Agricultural University, Bangladesh v. 9, n. 2, p. 205-210, 2011. DOI: 10.3329/jbau.v9i2.10987

DRISSI, S.; HOUSSA, A. A.; BAMOUH, A.; BENBELLA, M. Response of corn silage (Zea mays L.) to zinc fertilization on a sandy soil under field and outdoor container conditions. Journal of the Saudi Society of Agricultural Sciences, Amsterdam, v. 16, n. 2, p. 145-153, 2017. DOI: 10.1016/j.jssas.2015.05.002

EL-SHEIKH, M. H.; KHAFGY, S. A. A.; ZAIED, S. S. Effect of foliar application with some micronutrients on leaf mineral content, yield and fruit quality of Florida prince desert red peach trees. Journal of Agriculture and Biological Sciences, Bangladesh, v. 3, n. 4, p. 309-315, 2007.

EMPRESA BRASILEIRA DE PESQUISA AGROPECUÁRIA - EMBRAPA. National Center for Soil Research. Brazilian system of soil classification. 3. ed. Brasília: Embrapa, 2013. 353 p.

FAGERIA, N. K.; BALIGAR, V. C.; CLARK, R. B. Micronutrients in crop production. Advances in Agronomy, New York, v.77, p. 185-268, 2002. DOI: 10.1016/S0065-2113(02)77015-6

FANCELLI, A. L.; DOURADO NETO, D. Corn production. Guaíba: Agropecuária, 2000. 360 p. 
FERREIRA, A. C. B.; ARAÚJO, G. A. A.; PEREIRA, P. R. G.; CARDOSO, A. A. Corn crop characteristics under nitrogen, molybdenum and zinc fertilization. Scientia Agricola, Piracicaba, v. 58, n. 1, p. 131-138, 2001. DOI: 10.1590/S0103-90162001000100020

FERREIRA, D. F. Sisvar: a computer statistical analysis system. Ciência e Agrotecnologia, Lavras, v. 35 , n. 6, p. 1039-1042, 2011. DOI: 10.1590/S141370542011000600001

GALINDO, F. S.; TEIXEIRA FILHO, M. C. M.; BUZETTI, S.; SANTINI, J. M. K.; ALVES, C. J.; NOGUEIRA, L. M.; LUDKIEWICZ, M. G. Z.; ANDREOTTI, M.; BELLOTTE, J. L. M. Corn yield and foliar diagnosis affected by nitrogen fertilization and inoculation with Azospirillum brasilense. Revista Brasileira de Ciência do Solo, Viçosa, v. 40, e0150364, 2016. DOI: 10.1590/18069657rbcs20150364

GANMORE-NEUMANN, R.; DAVIDOV, S. Uptake and distribution of calcium in rose plantlets as affected by calcium and boron concentration in culture solution. Plant and Soil, Dordrecht, v.155-156, n. 1, p. 151-154, 1993. DOI: $10.1007 / \mathrm{BF} 00025006$

GUNESH, A.; ALPASLAN, M.; CHIKIL, Y.; OZCAN, $\mathrm{H}$. The effect of zinc on alleviation of boron toxicity in tomato plants (Lycopersicon esculentum L.). Turkish Journal of Agriculture and Forestry, Ankara, v. 24, n. 1, p. 505-509, 2000.

GUPTA, U. C.; KENING, W. U.; SIYUAN, L. Micronutrients in soils, crops and livestock. Earth Science Frontiers, Amsterdam, v. 15, n. 5, p.110-125, 2008. DOI: 10.1016/S1872-5791(09)60003-8

GUPTA, U. C. Boron and its role in crop production. Boca Raton, FL: CRC Press, 1993. 237 p.

HANSCH, R.; MENDEL, R. R. Physiological functions of mineral micronutrients $(\mathrm{Cu}, \mathrm{Zn}, \mathrm{Mn}, \mathrm{Fe}, \mathrm{Ni}, \mathrm{Mo}, \mathrm{B}$, $\mathrm{Cl})$. Current Opinion in Plant Biology, Amsterdam, v. 12, n. 3, p. 259-266, 2009. DOI: 10.1016/j.pbi.2009.05.006

HOSSEINI, S. M.; MAFTOUN, M.; KARIMIAN, N.; RONAGHI, A.; EMAM, Y. Effect of Zinc $x$ Boron interaction on plant growth and tissue nutrient concentration of corn. Journal of Plant Nutrition, New York, v. 30, n. 5, p. 773-781, 2007. DOI: 10.1080/01904160701289974

JAMAMI, N.; BÜLL, L.T.; CORRÊA, J.C.; RODRIGUES, J.D. Corn (Zea mays L.) culture response to boron and zinc soil application. Acta Scientiarum Agronomy, Maringá, v. 28, n. 1, p. 99-105, 2006. DOI: 10.1016/j.jssas.2015.05.002

KOBAYASHI, M.; NAKAGAWA, H.; ASAKA, T.; $\mathrm{MATOH}, \mathrm{T}$. Borate-rhamnogalacturonan II bonding reinforced by $\mathrm{Ca}_{2}^{+}$retains pectic polysaccharides in higher-plant cell walls. Plant Physiology, v. 119, n. 1, p. 199-203, 1999. DOI: 10.1104/pp.119.1.199

MALAVOLTA, E.; VITTI, G. C.; OLIVEIRA, S. A. Evaluation of the nutritional status of plants: principles and applications. 2. ed. Piracicaba: Brazilian Association for Research of Potash and Phosphate, 1997. 319 p.

MANZEKE, G. M.; MTAMBANENGWE, F.; NEZOMBA, H.; MAPFUMO, P. Zinc fertilization influence on maize productivity and grain nutritional quality under integrated soil fertility management in Zimbabwe. Field Crops Research, Amsterdam, v. 166, p. 128-136, 2014. DOI: 10.1016/j.fcr.2014.05.019

MARSCHNER, H. Mineral nutrition of higher plants. London: Academic Press Limited Harcourt Brace and Company Publishers, 2012. p. 347-364.

MENGEL, K.; KIKBY, E. Principles of plant nutrition. 5. ed. Dordrecht: Kluwer Academic Publishers, 2001. 849 p.

MUHMOOD, A.; JAVID, S.; NIAZ, A.; MAJEED, A.; MAJEED, T.; ANWAR, M. Effect of boron on seed germination, seedling vigor and wheat yield. Plant Soil and Environment, Praga, v. 33, n. 1, p. 17-22, 2014.

OJEDA-BARRIOS，D. L.; PEREA-PORTILLO，E.; HERNÁNDEZ-RODRÍGUEZ，O. A.; MARTÍNEZTÉLLEZ, J.; ABADÍA, J.; LOMBARDINI, L. Foliar fertilization with zinc in pecan trees. HortScience, Virginia, v. 49 , n. 5 , p. $562-566$, 2014. DOI: 10.21273 / HORTSCI.49.5.562

PRADO, R. M.; NATALE, W.; MOURO, M. C. Applied zinc sources way seed in the nutrition and initial growth of the corn cv. Fort. Bioscience Journal, Uberlândia, v. 23, n. 2, p. 16-24, 2007.

PRASAD, R.; SHIVAY, Y. S.; KUMAR, D. Interactions of zinc with other nutrients in soils and plants - A review. Indian Journal of Fertilizers, New Delhi, v. 12, n. 5, p. 16-26, 2016.

RAIJ, B. VAN; CANTARELLA, H.; QUAGGIO, J.A.; FURLANI, A. M. C. Fertilizer and lime recommendation for the State of São Paulo, Brazil. Campinas: Instituto Agronômico de Campinas, 1997. 285 p. (Boletim técnico, 100).

RAIJ, B. VAN; ANDRADE, J. C.; CANTARELLA, H.; QUAGGIO, J. A. Chemical analysis to evaluate the fertility of tropical soils. Campinas: IAC, 2001. 285p.

SHAMS, M.; ETEMADI, N.; BANINASAB, B.; RAMIN, A. A.; KHOSHGOFTARMANESH, A. H. Effect of boron and calcium on growth and quality of 'easy lover' cut rose. Journal of Plant Nutrition, New York, v. 35, n. 9, p. 
1303-1313, 2012. DOI: 10.1080/01904167.2012.684123

SINHA, P.; JAIN, R.; CHATTERJEE, C. Interactive effect of boron and zinc on growth and metabolism of mustard. Communications in Soil Science and Plant Analysis, New York, v. 31, n. 1-2, p. 41-49, 2000. DOI: 10.1080/00103620009370419

SONGKHUM, P.; WUTTIKHUN, T.; CHANLEK, N.; KHEMTHONG, P.; LAOHHASURAYOTIN, $\mathrm{K}$. Controlled release studies of boron and zinc from layered double hydroxides as the micronutrient hosts for agricultural application. Applied Clay Science, Amsterdam, v. 152, p.311-322, 2018. DOI: 10.1016/j. clay.2017.11.028

SOUZA, E. C. A.; COUTINHO, E. L. M.; NATALE, W.; BARBOSA, J. C. Response of corn to phosphorus and zinc fertilization. Pesquisa Agropecuária Brasileira, Brasília, v. 33, n. 7, p. 1031-1036, 1998.
TAVALLALI, V. Interactive effects of zinc and boron on growth, photosynthesis, and water relations in pistachio. Journal of Plant Nutrition, New York, v. 40, n. 11, p. 15881603, 2017. DOI: $10.1080 / 01904167.2016 .1270308$

TRAUTMANN, R. R.; LANA, M. C.; GUIMARÃES, V. F.; GONÇALVES JÚNIOR, A. C.; STEINER, F. Soil water potencial and boron fertilization in growth and uptake of the nutrient for the soybean crop. Revista Brasileira de Ciência do Solo, Viçosa, v. 38, n. 1, p. 240251, 2014. DOI: 10.1590/S0100-06832014000100024

YAMAUCHI, T.; HARA, T.; SONODA, Y. Effects of boron deficiency and calcium supply on the calcium metabolism in tomato plant. Plant and Soil, Dordrecht, v. 93 , n. 2, p.2 23-230, 1986. DOI: 10.1007/BF02374224 
